\title{
Essential oil of the leaves of Eugenia sulcata preserve myocardial contractility and does not present immunotoxicity
}

\author{
Karolina Torres Santos ${ }^{1}$, Fabricio Ocampo da Luz e Silva ${ }^{1}$, Leandro Alves Schneider ${ }^{1}$, Carlos \\ Eduardo Rangel dos Santos ${ }^{1}$, Sue Elle Berro da Silva ${ }^{1}$, Maquelen Blanco Fernandes ${ }^{1}$, Leandro \\ Rocha $^{2}$, Luís Flávio Souza de Oliveira ${ }^{1}$, Michel Mansur Machado ${ }^{1}$, Cleci Menezes Moreira*1
}

${ }^{1}$ Federal University of Pampa, Uruguayana, RS, Brazil, ${ }^{2}$ Department of Pharmaceutical Technology, Federal University

Fluminense, Niterói, RJ, Brazil

\begin{abstract}
The essential oil of the leaves of Eugenia sulcata, in the Myrtaceae family, has a demonstrated antihypertensive effect, but its effects on heart muscle and its toxicity have not yet been elucidated. Little chemical or biological data are available for E. sulcata, whether emphasizing the beneficial effects or the pharmacological security of this species. This study aims to evaluate myocardial contractility and to analyze angiotensin converting enzyme (ACE) and myosin ATPase activities associated with use of this essential oil. In addition, we evaluated the immunotoxicity of E. sulcata essential oil. Wistar Kyoto (WKY) and spontaneously hypertensive rats (SHR) were treated daily for 30 days ( $10 \mathrm{mg} / \mathrm{kg}$ of oil) to evaluate the isometric force of the papillary muscle, ACE measured by fluorimetry, and myosin ATPase activities by inorganic phosphate. Lymphocyte cultures were used to evaluate cytotoxicity, DNA damage, and mutagenicity of the essential oil. The results demonstrate that the treatment did not change the cardiac contraction force and did not alter the functioning of the sarcoplasmic reticulum, extrusion of the membrane calcium, or modify the membrane calcium channels or $\beta$-adrenergic receptor activity. Tetanic contractions were potentiated in the SHR animals. Myosin ATPase activity was also increased in the SHR animals. Cardiac ACE activity was reduced in both animal strains, and the serum ACE was reduced only in the SHR animals. The essential oil did not cause cytotoxicity or mutagenicity and presented low DNA damage. Our results demonstrated that the essential oil does not change myocardial contractility and does not present relevant immunotoxicity.
\end{abstract}

Keywords: Myrtaceae/adverse effects. Angiotensin-Converting Enzyme Inhibitors/immunology.

\section{INTRODUCTION}

Many medicinal plants are used by the human population for the treatment of pathologies affecting the cardiovascular system, such as hypertension. However, the safety, effectiveness, and mechanism of action have been scientifically confirmed for only a few of these plants (Vora, Mansoor, 2005). Eugenia sulcata Spring ex Mart. (family Myrtaceae) is an endemic species of the Atlantic Rainforest and popularly used for diarrhea and fever (Cruz, Kaplan, 2004); it is commonly known as murtinha or murta preta in Restinga de Jurubatiba National Park (Santos et al., 2009).

\footnotetext{
*Correspondence: Cleci Menezes Moreira. Federal University of Pampa, BR 472 - Km 585- Mailbox 118, 97501-970 - Uruguayana, RS, Brazil. Phone: (55)3911 0200. E-mail: clecim2@gmail.com iD
}

Previous studies carried out by our group have demonstrated the hypotensive and antihypertensive effect (Santos et al., 2013, 2014) and anticholinesterase activity (Lima et al., 2012) of E. sulcata essential oil. Lima et al. (2012) analyzed the constituents in essential oil from the leaves of E. sulcata and found 22 components, mainly $\alpha$ and $\beta$ pinene, $\beta$ caryophyllene, and 1.8 cineol, and these compounds could be involved in these activities.

It is known that clove oil contains $\beta$ caryophyllene oxide and eugenol, and when analyzing the force of cardiac contraction, a significant decrease was observed in treated animals (Sensch et al., 2000). There are few chemical, biological, or toxicological scientific studies of E. sulcata, and there are no studies to evaluate the pharmacology and toxicology of this oil to ensure its safety and efficacy.

Several factors are involved in hypertension, and key enzymes have been considered in relation to this pathology. 
Activation of the renin-angiotensin-aldosterone system (RAAS) is one of the most important mechanisms contributing to endothelial cell dysfunction, hypertension, and vascular remodeling (Ferrario et al., 2014). Renin and angiotensin-I converting enzyme (ACE) are the two key enzymes that regulate the renin-angiotensin system, and they are important determinants of blood pressure and fluid homeostasis (Daien et al., 2012). Reports of plant essential oils and extracts with inhibitory action in ACE activity indicate that they could be a promising therapeutic adjuvant (Mansour et al., 2013; Jaarin et al., 2015; Sharifi et al., 2013).

One of the organs most affected by hypertension is the heart. Several pathological cardiac events arising from both volume and pressure overload or metabolic changes can trigger modifications in myocardial contractility proteins. The major molecules involved in the contractionrelaxation cycle are the two main contractile proteins: the thin segment, actin, and the thick segment, myosin. The cycle of contraction occurs, in terms of biochemistry, through the hydrolysis of adenosine triphosphate (ATP) on adenosine diphosphate (ADP) and inorganic phosphate (Pi) by the ATPase activity of the myosinic head flexing it (Libby et al., 2008).

The use of plants in therapeutic regimens has been increasing over the years. It is estimated that Brazil has the greatest genetic diversity on the planet (Almeida, 2003), and it is a rich source of plant inputs that can aid in the treatment and prevention of many diseases (Simões et al., 2007). Despite their great medicinal importance, the toxicity of most Brazilian plants is not known, making it a research area that should be incentivized. Our study therefore evaluates myocardial contractility and immunotoxicity in human lymphocytes in order to increase the available knowledge about $E$. sulcata.

\section{MATERIAL AND METHODS}

\section{Plant material}

Leaves of Eugenia sulcata were collected in Restinga of Jurubatiba National Park, Rio de Janeiro State, Brazil, from Clusia scrub vegetation $\left(22^{\circ} 12^{\prime} 57.7^{\prime}\right.$ 'S $41^{\circ} 34^{\prime} 58.5^{\prime \prime} \mathrm{W}$ ) in July 2013 . A voucher specimen was deposited at the herbarium of the Faculdade de Formação de Professores (Universidade do Estado do Rio de Janeiro, Brazil) under the register number RFFP 13.788. The extraction of the oil and the identification of the components were carried out according to Lima et al. (2012).

\section{Animals}

A total of 16 male Wistar Kyoto (WK) rats and 16 spontaneously hypertensive rats (SHR), 200-250g weight and 12 weeks old, were purchased from Fundação Estadual de Produção e Pesquisa em Saúde (FEPPS) and were maintained in the Federal University of Pampa, campus Uruguayana, RS, Brazil. They were used after acclimatization for 1 week. They were kept under conditions of constant temperature $\left(22-25^{\circ} \mathrm{C}\right)$ with an artificial $12 \mathrm{~h}$ light/dark cycle; all rats received food and water ad libitum. The experimental protocol was carried out according to the COBEA guidelines (Brazilian College of Animal Experimentation) and was approved by the Animal Ethics Committee of the Federal University of Pampa (No. 34/2015).

\section{Experimental groups}

Rats were divided into four experimental groups of eight rats each. Two control groups of WKY rats and SHR rats received dimethyl sulfoxide (DMSO, $0.5 \%$ in saline, i.p. used as vehicle). Two treated groups of WKY rats and SHR rats received essential oil diluted in the vehicle. Rats were treated for 30 days with daily dose injections ( $10 \mathrm{mg} /$ $\mathrm{kg}$, i.p.) in a final volume of $200 \mu \mathrm{L}$ (Santos et al., 2014).

The treatment time and the dose used were based on previous studies with E. sulcata (Santos et al., 2013; 2014).

\section{Myocardial contractility}

The animals were anaesthetized $(75 \mathrm{mg} / \mathrm{kg}$ ketamine and $100 \mathrm{mg} / \mathrm{kg}$ xylazine), and the chest was opened to collect the heart. The papillary muscles of the left ventricle (LV) were dissected and placed on a nourishing solution $(20 \mathrm{~mL})$ of Krebs-Henseleit buffer, $\mathrm{pH}$ 7.4, aerated with $5 \% \mathrm{CO}_{2}$ and $95 \% \mathrm{O}_{2}$ at $29^{\circ} \mathrm{C}$. The muscles were fixed by rings, tied to a fixed end, and attached to a force transducer. The papillary muscles were electrically stimulated through a pair of platinum electrodes positioned along the entire length of the muscle (rectangular pulses with duration of 12 milliseconds and voltage 1.5 times the threshold), with stimulation frequency of $0.5 \mathrm{~Hz}$, and the muscles were stretched to Lmax (muscle length at which the maximum voltage is active). The preparations were maintained for a 30-minute stabilization period before initiation of the experimental protocols.

\section{Isometric force}

The force developed was normalized by the muscle 
weight ( $\mathrm{g} / \mathrm{mg}$ muscle) and measured by means of an isometric force transducer (TSD125, Biopac Systems, Inc., CA) coupled to an amplifier (DA100C, Biopac Systems, Inc., CA) and recorded by a data acquisition system (BIOPAC MP100 Systems, Inc., CA) connected to a microcomputer. The data were recorded at 500 samples/ second.

\section{Potentiation after pauses}

The relative potentiation after pauses of 15,30 , and 60 seconds was obtained in order to indirectly evaluate the contribution of sarcoplasmic reticulum (SR) in contraction. The ratio of the amplitude of contraction after the pause and the amplitude of the previous contraction to the pause was considered.

\section{Frequence of stimulation}

The strength was developed in different frequencies of electrical stimulation in the papillary muscles (from 0.1 to $1.0 \mathrm{~Hz})$.

\section{Inotropic effect of calcium}

The inotropic dose-response curve to calcium in increasing concentrations of $\mathrm{CaCl}_{2}(0.62 ; 1.25 ; 2.50$ and $3.75 \mathrm{mM}$ ) was measured. Response to calcium was measured in $\mathrm{g} / \mathrm{mg}$.

\section{Beta-adrenergic response}

The beta-adrenergic response to isoproterenol $\left(10^{-5}\right.$ M) evaluates the interference of treatment on $\beta$-adrenergic response in the heart muscle. It was normalized as the ratio of the maximum amplitude in the force of contraction in the presence of isoproterenol and the amplitude to contraction previous isoproterenol (Leite, Vassallo, Millet, 1995).

\section{Tetanic contractions}

Assessment of the effects of the essential oil on tetanic contractions was obtained after 30 minutes of treatment with $5 \mathrm{mM}$ caffeine at a frequency of $10 \mathrm{~Hz}$ and duration of 15 seconds, as previously described (Vassallo et al., 2008).

\section{Heart hypertrophy analysis}

The animals' body weight was measured daily. The right ventricle was separated from the LV, and interventricular septum was considered part of the LV. The ratio of ventricular weight to body weight (LV/BW) was used as an index for estimation of cardiac hypertrophy as described by Piratello et al., 2010, and Campos et al., 2015.

\section{Evaluation of the specific activity of myosin ATPase}

The preparation of the myosin fraction was performed according to Bremel and Weber (1975) and described by Moreira et al. (2003). Part of the LV of the rats after treatment was homogenized in $150 \mathrm{mM}$ phosphate buffer solution containing $0.6 \mathrm{M} \mathrm{KCl,} \mathrm{pH} 6.5$ (this procedure solubilizes myosin), precipitated with the slow addition of water, centrifuged at $30,000 \times g$ for $30 \mathrm{~min}$. The precipitate was solubilized in phosphate buffer with $0.6 \mathrm{M} \mathrm{KCl}$ and again centrifuged at $30,000 \times g$ for $30 \mathrm{~min}$. These centrifugation procedures were performed two more times. The latter precipitate was resuspended in $50 \mathrm{mM}$ HEPES, $\mathrm{pH} 7.0,0.6 \mathrm{M} \mathrm{KCl}$, and $50 \%(\mathrm{v} / \mathrm{v})$ glycerol, then aliquoted and stored at $-80^{\circ} \mathrm{C}$.

For the biochemical evaluation of the heart's ability to generate contractile force, the myosin ATPase activity was determined using a buffer medium ( $\mathrm{pH} 7.0)$ containing $50 \mathrm{mM}$ HEPES, $5 \mathrm{mM} \mathrm{CaCl}_{2}, 0.6 \mathrm{M} \mathrm{KCl}$, and $1 \mathrm{mMATP}$ (Moreira et al., 2003). The incubation time and amount of protein added to the reaction medium were chosen to ensure the linearity of product formation at $30^{\circ} \mathrm{C}$. The reaction was initiated by the addition of the myosinic fraction. The reaction was stopped by the addition of trichloroacetic acid (TCA) to a final concentration of 5\%. The final product in the reaction was inorganic phosphate (Pi), which was measured according to the method of Chan, Delfert, and Junger (1986). Samples were assayed in triplicate, with the non-enzymatic hydrolysis corrected by controls made under the same sample conditions, except that the enzymatic fraction was added after discontinuation of the TCA reaction. The specific activity was expressed in nmol of phosphate released per minute and per $\mathrm{mg}$ of protein (nmol Pi/min/mg). Protein was quantified by the method of Bradford (1976) using bovine albumin $(1 \mathrm{mg} / \mathrm{mL})$ as standard.

\section{Angiotensin converting enzyme activity}

The effect of the essential oil in ACE activity was determined as previously described by Oliveira, Santos, and Krieger (2000). The animals' blood was collected from the abdominal aorta, and serum samples were incubated in $40 \mu \mathrm{L}$ buffer $(0.4 \mathrm{M}$ sodium borate, $0.9 \mathrm{M}$ $\mathrm{NaCl}, \mathrm{pH} 8.3), 5 \mu \mathrm{L}$ substrate hippuryl-histidyl-leucine (5 mM Hip-His-Leu) for $15 \mathrm{~min}$ at $37^{\circ} \mathrm{C}$. The reaction was stopped by adding $190 \mu \mathrm{L}$ of $0.34 \mathrm{~N} \mathrm{NaOH}$. The Hip-His-Leu product was measured by fluorometry at $365 \mathrm{~nm}$ excitation and $495 \mathrm{~nm}$ emission after the addition of $17 \mu \mathrm{L}$ of o-phthaldialdehyde (2\%) in methanol. To 
correct the intrinsic fluorescence of the serum, blanks were included by adding Hip-His-Leu and o-phthaldialdehyde. For cardiac ACE determination, part of each animal's LV was homogenized in borate buffer $(100 \mathrm{mg}$ tissue $/ \mathrm{mL}$ buffer). Samples $(10 \mu \mathrm{L})$ were incubated as described above for serum ACE. The calibration curve with the product (Hip-His-Leu) was included in each experiment.

\section{Culture cell preparation}

Lymphocyte cultures were prepared with human whole-blood samples and immediately transferred to $10 \mathrm{~mL}$ of culture medium containing RPMI 1640 supplemented with $10 \%$ fetal bovine serum and 1\% streptomycin/ penicillin, as previously described (Santos-Montagner et al., 2010). The Research Ethics Committee of the Federal University of Pampa (No. 27045614.0.0000.5323) approved the use of human blood. Cells were maintained at $37^{\circ} \mathrm{C}$ in a $5 \% \mathrm{CO}_{2}$ environment. Every $72 \mathrm{~h}$, the medium was exchanged with another prepared in the same manner. Cells were maintained in this manner until the time of use. All cultures received the addition of the test compound in a final volume of $100 \mu \mathrm{L}$. The groups to be tested were: negative control (NC) with phosphate buffer (PBS) pH 7.4, genotoxic positive control (PC) with hydrogen peroxide $\left(\mathrm{H}_{2} \mathrm{O}_{2}\right)(10 \mu \mathrm{M})$, and 3 concentrations of E. sulcata (ES) essential oil $(1,10$, and $100 \mu \mathrm{g} / \mathrm{mL})$.

\section{Immunotoxicological analysis}

To perform the genotoxicity tests, we first counted the total number of lymphocytes in a Neubauer chamber (Santos-Montagner et al., 2010). Viability was assessed by loss of membrane integrity, which was indicated with trypan blue (Burow et al., 1998). Overall, we counted 300 cells. The genotoxicity test was conducted using comet assay (Singh et al., 1995). Although comet assay is not the only method for measuring oxidative DNA damage, it is one of the most sensitive and accurate and is relatively free of artifacts. The cells were visually scored according to tail length, with scores ranging from 0 (no migration) to 4 (maximal migration). The damage index for cells therefore ranged from 0 (all cells with no migration) to 400 (all cells with maximal migration). The micronucleus test was the parameter used to evaluate mutagenicity. The method was performed according to the technique described by Schmid (1975) and presented in index form as described by Fenech (2000).

\section{Statistical analysis}

The results were expressed as mean \pm mean standard error $(\mathrm{M} \pm \mathrm{SEM})$. The values were analyzed using a two-way ANOVA (Figures $1 \mathrm{~A}-1 \mathrm{~F}$ and 3 ) and unpaired Student's t-test (Figures 1H and 2), with post hoc Bonferroni. Mean differences were considered statistically significant with $p<0.05$.

\section{RESULTS}

\section{Myocardial contractility}

The isometric force exerted by the papillary muscle of the LV is shown in Figure 1A. The results demonstrate that treatment with the essential oil of E. sulcata leaves did not impair the force of cardiac contraction. There was no difference in calcium inotropic effect with treatment, suggesting that the essential oil of E. sulcata did not interfere in the membrane calcium channels (Figure 1B). In relative potentiation after pauses, Figures $1 \mathrm{C}$ and $1 \mathrm{D}$ show that at the times of 15,30 , and 60 seconds, there was no change in the force developed. The force developed in the different frequency of electrical stimulation shows that there was no change in the two rats strains tested (Figure 1E and $1 \mathrm{~F}$ ). The administration of isoproterenol ( $\beta$-adrenergic agonist) did not increase the force developed by the papillary muscles (Figure $1 \mathrm{G}$ ). Figure $1 \mathrm{H}$ shows tetanic cardiac contractions, where it was observed that they were potentiated in hypertensive and WK rats.

\section{Heart hypertrophy analysis}

In the index of cardiac hypertrophy, a decrease in the VE/body weight ratio was observed in both SHR and WK animals (Figure 2A).

\section{Evaluation of the specific activity of myosin ATPase}

Figure 2B demonstrates a significant increase of myosin ATPase-specific activity in hypertensive animals treated with essential oil from E. sulcata leaves.

\section{Angiotensin converting enzyme activity}

The activity of the angiotensin-converting enzyme was assessed in cardiac tissue and serum. There was a decrease in cardiac activity in SHR and WK; however, in serum ECA there was decrease only in SHR treated with essential oil from E. sulcata leaves (Figures 2C and 2D).

\section{Immunotoxicological analysis}

Figure $3 \mathrm{~A}$ shows the cell viability for human 
A

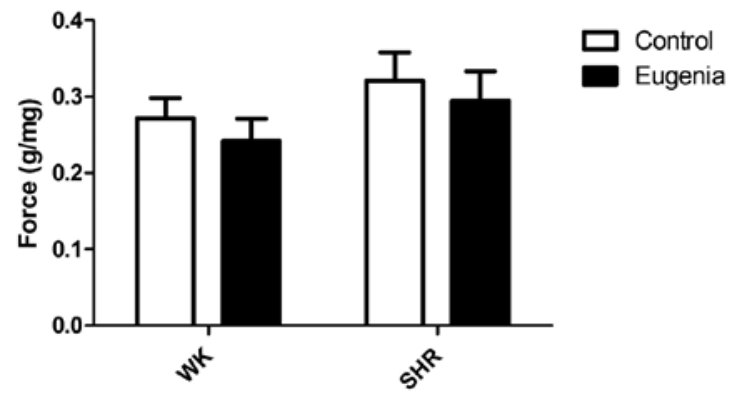

C

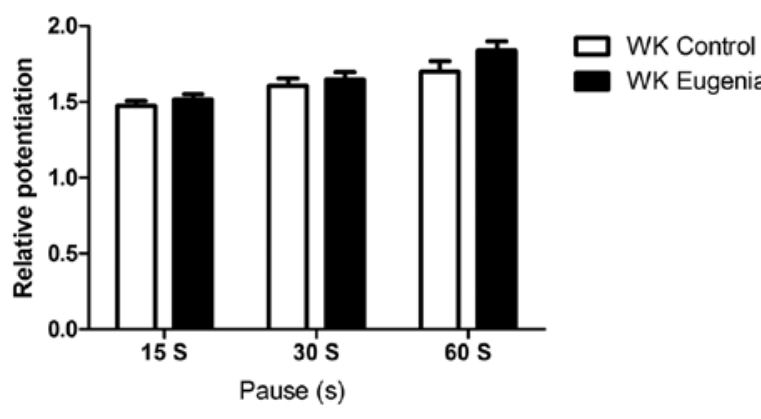

E

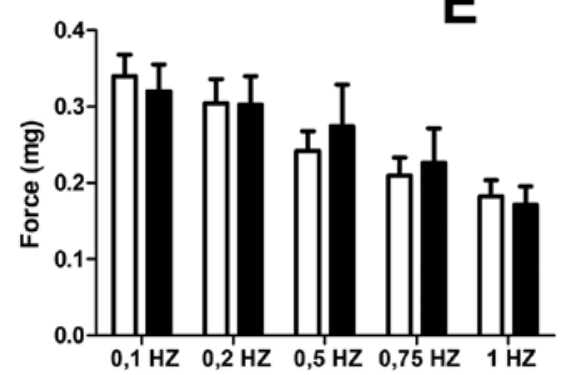

G

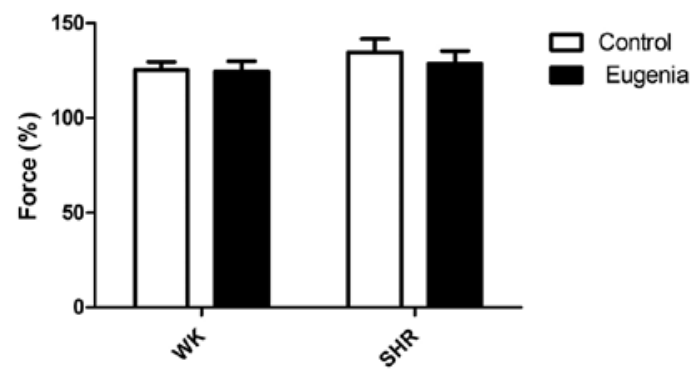

B

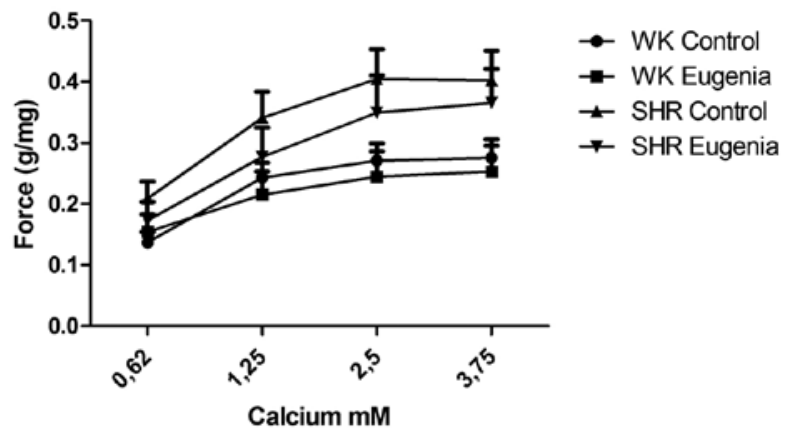

D

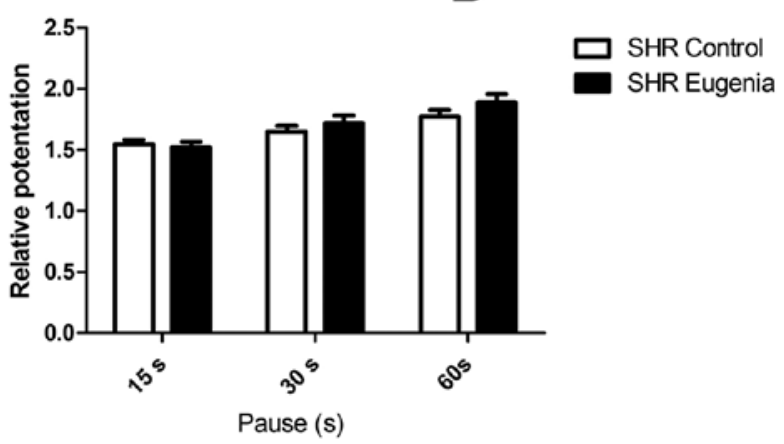

$\mathbf{F}$
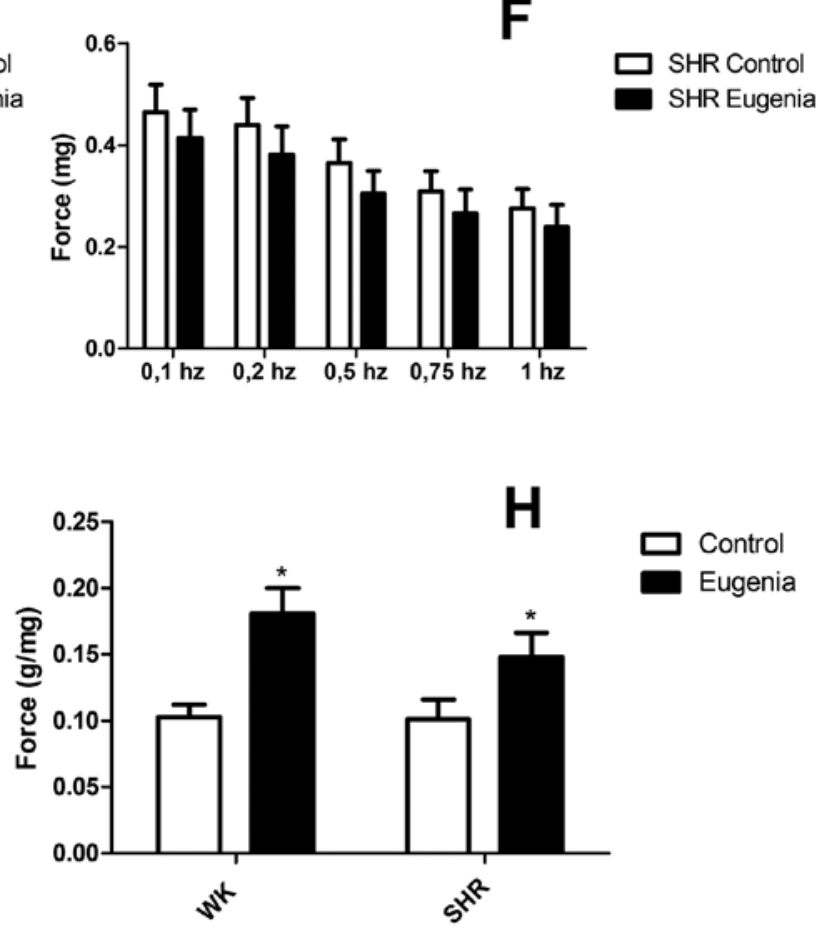

FIGURE 1 - Myocardial contractility of the Left ventricle (LV) papillary muscle of rats treated for 30 days with the essential oil of Eugenia sulcata leaves (10 mg/kg). Legend: (A) Isometric force. (B) Inotropic effect of calcium $(0.62-3.75 \mathrm{mM} \mathrm{CaCl})$. (C) Relative potentiation after pauses (15, 30, and $60 \mathrm{~s}$ ) in Wistar Kyoto (WK). (D) Relative potentiation after pauses $(15,30$, and $60 \mathrm{~s}$ ) in spontaneously hypertensive animals (SHR). (E) Strength of the different frequencies of electrical stimulation in WK. (F) Strength of the different frequencies of electrical stimulation in SHR. (H) Tetanic contractions. ${ }^{*} p<0.05$ vs Control. ANOVA and Student's t-Test. 

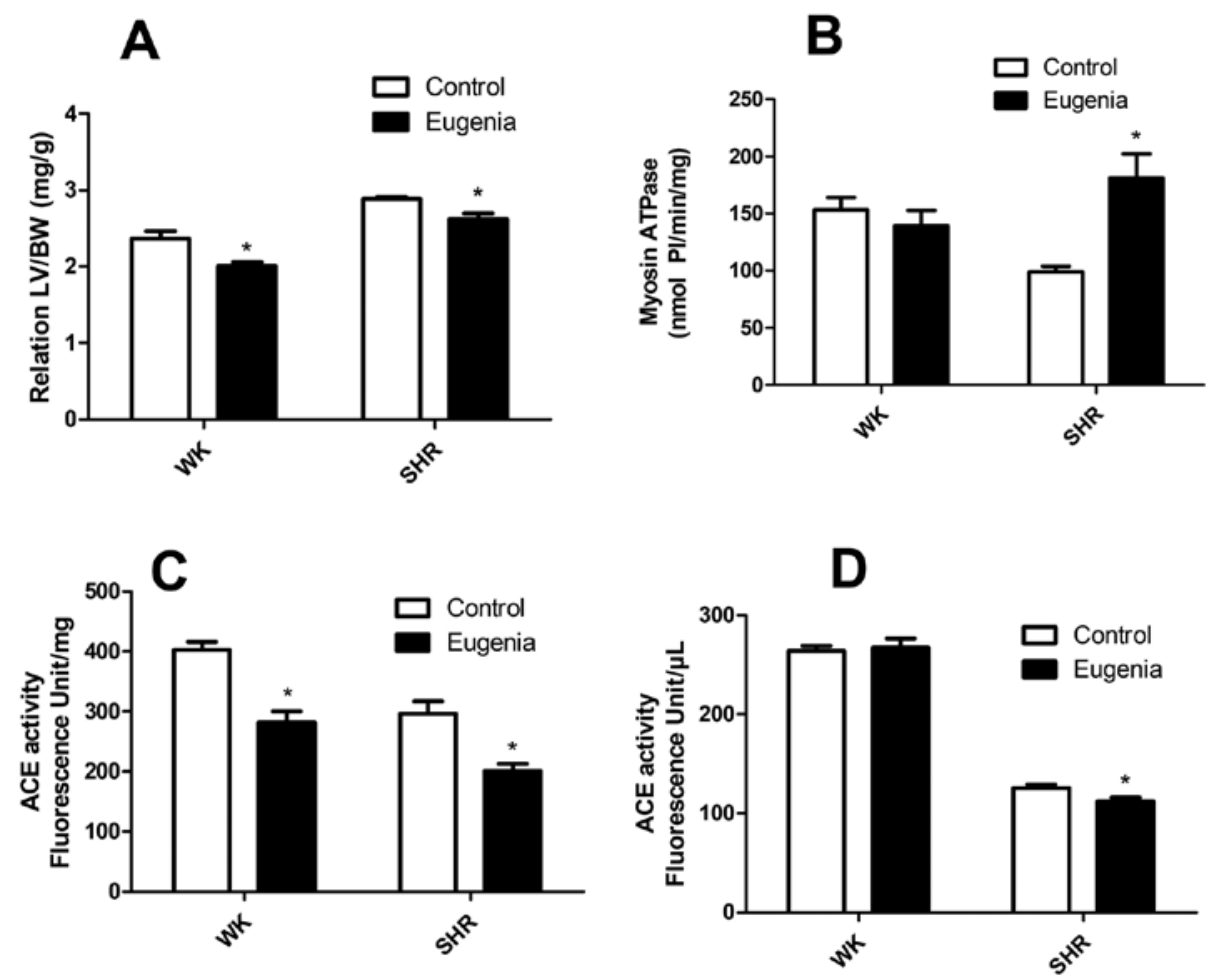

FIGURE 2 - Evaluation of the cardiac hypertrophy index and biochemical evaluations in rats treated for 30 days with the essential oil of the leaves of Eugenia sulcata $(10 \mathrm{mg} / \mathrm{kg})$. Legend: (A) LV cardiac hypertrophic index. Left Ventricular Weight/Body Weight (LV/BW) (B) Myosin ATPase activity in LV myosin preparations. (C) Serum angiotensin converting enzyme activity (ACE). (D) Activity of the ACE in the LV homogenate. ${ }^{*} p<0.05$ vs Control and ${ }^{\#} p<0.05 v s$ WK Control. Student's t-Test).

lymphocytes treated with different concentrations of E. sulcata essential oil. It was verified that the positive control (PC) reduced cell viability by $11 \%$ compared to the negative control (NC) whereas no effect was detected with the oil treatment. In the mutagenicity analysis that tested for the frequency of micronuclei for human lymphocytes, there were no statistical differences in the concentrations of the essential oil when compared to the $\mathrm{NC}$, and all the concentrations of the oil were significantly different from the PC, showing no mutagenicity (Figure 3B). Figure 3C, which evaluates the DNA damage index through the comet test, shows a difference between the $\mathrm{NC}$ and $\mathrm{PC}$ groups and indicates that all concentrations of the oil of E. sulcata leaves showed significant damage when compared to the NC group. However, the oil in the different concentrations shows an increase in the DNA damage index of a maximum of $50 \%$ when compared to the PC.

\section{DISCUSSION}

The isometric force of the papillary muscle was used to evaluate the myocardial contractility of the LV papillary muscles in animals treated with E. sulcata oil for 30 days. It was observed that treatment did not modify the force in either WK or SHR animals, demonstrating that there was no impairment in myocardial contractility at the concentration used and in the evaluated period (Figure 1A).

A negative inotropic effect has been observed in mice with the administration of the essential oil of the leaves of Schinus areira L., the main constituents of which are $\beta$ caryophyllene and $\alpha$ pinene (Bigliani et al., 2012). Although E. sulcata essential oil has the same major constituents, it did not decrease the force of cardiac contraction in this study. However, this oil is able to reduce blood pressure in hypertensive animals (Santos et $a l ., 2014$ ) without causing damage to cardiac contraction force.

In the myocardium, the influx of $\mathrm{Ca}^{2+}$ stimulates the release of $\mathrm{Ca}^{2+}$ from the intracellular stock of SR, with subsequent transient increase of the intracellular concentration of $\mathrm{Ca}^{2+}$, which results in the activation of myofilaments, producing muscle contraction (Bers, 2002). Calcium plays a crucial role in regulating the contraction and relaxation phase of the cardiac muscle. The increase in the concentration of cytosolic calcium also causes its interaction with troponin $\mathrm{C}$ to increase and activates the contractile process; that is, the greater the amount of available calcium, the greater the force generated (Bers, 

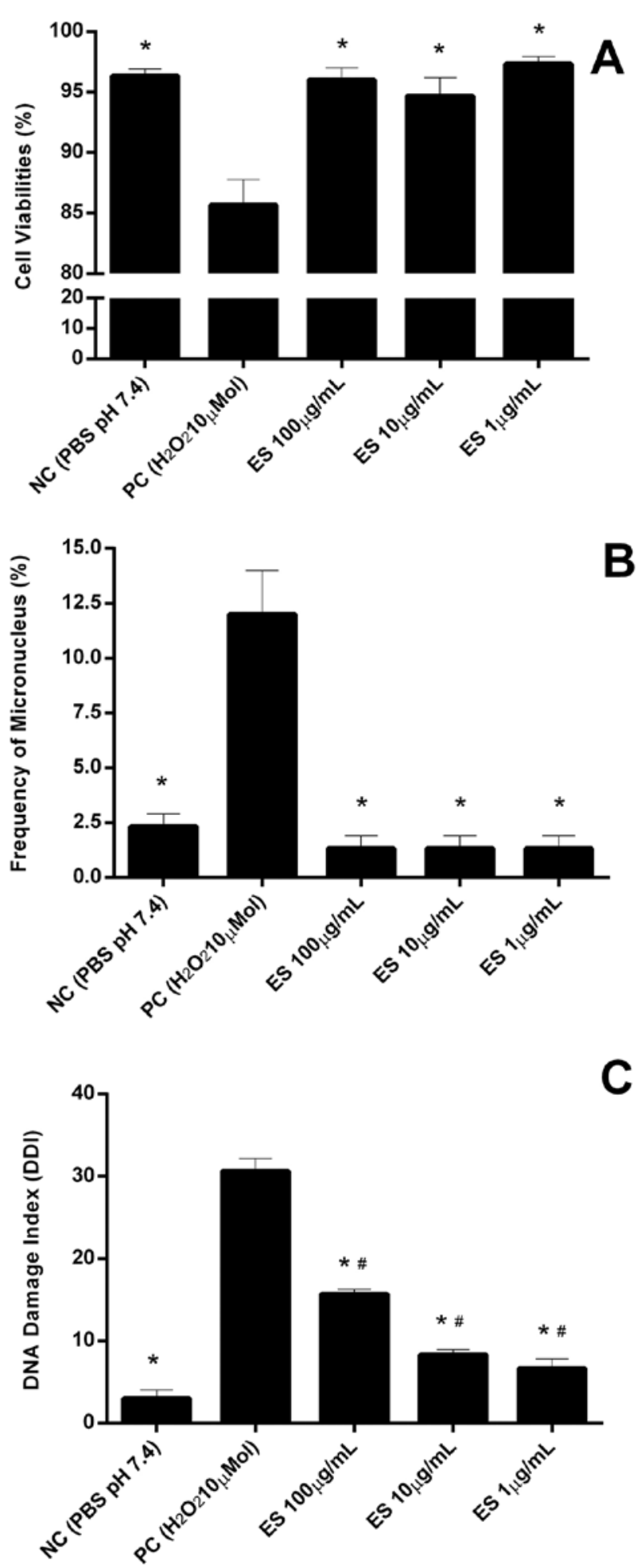

FIGURE 3 - Immunotoxicological analysis of the essential oil treatment of Eugenia sulcata leaves $(1,10$, and $100 \mu \mathrm{g} / \mathrm{mL})$ on human lymphocytes. Legend: Eugenia sulcata (ES), negative control with phosphate buffer (PBS) (NC), positive control with hydrogen peroxide $\left(\mathrm{H}_{2} \mathrm{O}_{2}\right)(\mathrm{PC})$. (A) Cell viability assessment. (B) Evaluation of DNA damage index by comet assay. (C) Micronucleus frequency evaluation. ${ }^{*} p<0.05$ vs PC and ${ }^{\#} p<0.05$ vs NC. ANOVA.
2002). There was no difference in the calcium inotropic effect with treatment, suggesting that the essential oil of E. sulcata did not interfere in the membrane calcium channels (Figure 1B).

Post pause potentiation (PPP) was performed to determine whether essential oil could interfere with the function of the SR, an important organelle in the generation of contractile force. It is known that in mammalian cardiac muscles the first contraction is potentiated after a short pause period (Vassallo et al., 2008).

The contractions obtained after pauses are more dependent on the release of calcium by their intracellular stokes than by the influx of calcium by the sarcolemma. In this way, PPP measurements aim to evaluate the activity of SR, both in terms of the magnitude of release of activating calcium and the capacity of calcium reuptake (Mill et al., 1994). It was observed that E. sulcata oil did not modify the SR function, since at all tested times (15, 30 , and 60 seconds) there were no significant differences in the strength developed by the treated animals (Figure $1 \mathrm{C}$ and 1D).

The force developed at different frequencies of electrical stimulation can be objectively assessed in papillary muscles if calcium-extruding mechanisms are preserved in the LV. No change was observed in the development of strength at different frequencies of electrical stimulation of the animals in both experimental groups (Figure 1E and 1F); therefore, we can suggest that the myocytes of those rats treated for 30 days had unchanged calcium extrusion mechanisms (Mill et al., 1994).

The beta-adrenergic activation of the heart muscle culminates in the phosphorylation of membrane calcium channels and ryanodine channels, leading to an increase in intracellular calcium (Negroni et al., 2015). As shown in Figure $1 \mathrm{G}$, treatment with E. sulcata showed no change in this parameter.

The cardiac muscle action potential is long, which prevents the myocyte from suffering re-stimulation and tetanization, so cardiac tetanus cannot be reached in normal conditions. Caffeine was used to tetanize the cardiac muscle, which depletes calcium SR to keep open the ryanodine channels (Bassani, Bassani, Bers, 1994). The frequency of electrical stimulation at $10 \mathrm{~Hz}$ was used to stimulate the maximal activation of the cardiac machine of the papillary muscles (Leite, Vassallo, Millet, 1995). The tetanic contraction occurs via transmembrane calcium channel inflow (because the ryanodine channels does not function) and by sensitization of contractile proteins (Leite, Vassallo, Millet, 1995). The essential oil treatment showed an increase in tetanic contraction force, 
which suggests that it can influence the sarcolemmal entry calcium and/or the sensitivity of myofilaments, (Figure $1 \mathrm{H})$.

In hypertensive patients, left ventricular hypertrophy (LVH) is a powerful independent predictor of morbidity and mortality (Tamargo, Delpón, Valenzuela, 1993). The weight ratio LV/BW is considered an index of ventricular hypertrophy. The essential oil treatment was capable of decreasing the $\mathrm{LV} / \mathrm{BW}$ ratio in treated SHR and also in treated WK animals (Figure 2A), demonstrating hypotrophic and antihypertrophic effects. The animals were monitored daily (data not shown), and there was no significant difference in body weight for either group during the treatment time.

Myosin is a contractile protein that changes the expression of its heavy chain isoforms (alpha to beta MHC) with a pressure overload in an attempt to maintain force generation. The alpha-MHC isoform has an ATP hydrolysis rate greater than the beta-MHC isoform (Barany 1967; Hoh et al., 1979; Syrovy, Delcayre, Swynghedauw, 1979). Some essential oils exhibit a negative inotropic effect without altering the activity of myosin (Damiani et al., 2004), but E. sulcata oil did not alter the contraction force (Figure 1A), possibly due to the increase in myosin activity, preserving the alpha MHC isoforms (Barany, 1967).

Figure 2B demonstrates a myosin ATPase-specific activity of the rats treated with essential oil from $E$. sulcata leaves. It was observed that there was a significant increase in enzyme activity in hypertensive animals, suggesting an improvement in the percentage of isoforms with the higher ATP rate (alpha-MHC).

We observed that the cardiac ACE activity showed a significant decrease in both the WK and SHR treated animals, and when ACE was measured in serum, there was a significant decrease only in hypertensive animals, meaning that $E$. sulcata essential oil showed an inhibition of ACE activity, as shown in Figures $2 \mathrm{C}$ and 2D. Inhibition of ACE activity results in lower production of Angiotensin II, which is a potent vasoconstrictor; thus it is able to contribute to the regulation of blood pressure and cardiac muscle integrity. Other essential oils also show inhibition of ACE in experimental animals (Mansour et al., 2013; Jaarin et al., 2015).

The essential oil of E. sulcata presents antihypertensive effect (Santos et al., 2014), and, to our knowledge, this study demonstrates for the first time the evaluation of relevant cardiac enzymes and cardiac mechanics. Although the essential oil did not alter the contraction force, it showed an increase in the activity of the force-generating enzyme (myosin ATPase) and in the enzyme involved in the antihypertensive activity (ACE), which suggests that this essential oil can be used for the treatment of hypertension while preserving myocardial contractility.

The cell viability for human lymphocytes, shown in Figure 3A, was tested at three concentrations of $E$. sulcata essential oil. It was verified that, while the positive control (PC) decreased cell viability, this reduction in cell viability was not observed with essential oil when compared to the negative control (NC). These results show that the oil had no cytotoxic effect at the concentrations tested. When investigating the cytotoxic effect of the $\alpha$ pinene compound, $50 \mu \mathrm{g} / \mathrm{mL}$ cultures of fibroblasts, the authors found low cytotoxicity (Sobral-Souza et al., 2014). The hydroalcoholic extract of Euphorbia tirucalli was evaluated in a leukocyte cell culture, and the authors demonstrated that there was an increase in the percentage of non-viable cells with the increase of extract concentrations that were administered, showing a cytotoxic effect at high concentrations of E. tirucalli (Machado et al., 2016). Machado et al. (2016) has in its research the basis of the use of the trypan test, which supports both the evaluation of cytotoxicity per se and the need, as a screening test, to give reliability to the results of other tests, especially genotoxicological tests. However, the trypan blue test is limited to an assessment of cell membrane damage, so it does not exclude the possibility that other metabolic-functional mechanisms are present or support cytotoxicity results.

The frequency of micronuclei for human lymphocytes was tested for mutagenicity (Figure 3B). The treatment appeared to have no mutagenic effect for lymphocytes. Corroborating our data, Turkez and Aydin (2016) evaluated the effect of human lymphocyte exposure to $\alpha$ pinene, which did not undergo significant changes. In contrast, Catanzaro et al. (2012) demonstrated that $\alpha$ pinene, to promote significant changes in the frequency of micronuclei, as well as the hydroalcoholic extract of E. tirucalli, showed a higher frequency of micronuclei, indicating a genotoxic risk (Machado et al., 2016).

Evaluation of the DNA damage index (Figure $3 \mathrm{C})$ was performed through the comet test. The tested concentrations of essential oil yielded significant damage when compared to the negative control. However, this oil caused less damage to DNA than hydrogen peroxide (PC), thus demonstrating a low genotoxicity at the concentrations tested.

Our immunotoxicity results, although presenting low DNA damage, did not show cytotoxic effects, did not present mutagenicity, and thus E. sulcata could be considered a potentially safe essential oil for use in 
cardiovascular diseases. Even though there are some studies in the literature using medicinal plants, studies on essential oils still have not sufficiently verified the possible toxic effects of plants that are commonly used by the population.

\section{CONCLUSION}

The essential oil of the leaves of E. sulcata does not change the isometric force generation capacity in the SHR and WK treated animals, demonstrating that there was no impairment in the myocardial contractility; however, tetanic contractions were potentiated in the SHR animals, and there was improvement in myosin ATPase activity and inhibition of ACE activity. This oil were found not to cause cytotoxicity or mutagenicity, and it showed low genotoxicity. In summary, the essential oil of the leaves of E. sulcata at a concentration of $10 \mathrm{mg} / \mathrm{kg}$ was shown to be beneficial to the cardiovascular system of rats and presented low immunotoxicity in human lymphocytes.

\section{DECLARATION OF INTEREST}

The authors report that they have no conflicts of interest.

\section{ACKNOWLEDGMENTS}

The authors to thank PPSUS/FAPERGS for the financial support.

\section{REFERENCES}

Almeida MZ. Plantas medicinais. 2.ed. Salvador: EDUFBA. 2003; p.216.

Barany, M. ATPase activity of myosin correlated with speed of muscle shortening. J Gen Physiol. 1967;50(2):197-216.

Bassani JWN, Bassani RA, Bers DM. Relaxation in rabbit and rat cardiac cells: species-dependent differences in cellular mechanisms. J Physiol. 1994;476(2):279-293.

Bers DM. Cardiac excitation-contraction coupling. Nature. 2002;415(6868):198-205.

Bigliani MC, Rossetti V, Grondona E, Lo Presti S, Paglini PM, Rivero V, et al. Chemical compositions and properties of Schinus areira L. essential oil on airway inflammation and cardiovascular system of mice and rabbits. Food Chem Toxicol. 2012;50(7):2282-2288.
Bradford MM. A rapid and sensitive method for the quantification of microgram quantities of protein utilizing the principle of protein-dye binding. Anal Biochem. 1976;72:248-254.

Bremel RD, Weber A. Calcium binding to rabbit skeletal myosin under physiological conditions. Biochim Biophys Acta. 1975;376(2):366-374.

Burow ME, Weldon CB, Tang Y, Navar GL, Krajewski S, Reed JC, et al. Differences in susceptibility to tumor necrosis factor alpha-induced apoptosis among MCF-7 breast cancer cell variants. Cancer Res. 1998;58(21):4940-4946.

Campos JC, Fernandes T, Bechara LRG, Paixão NA, Brum PC, Oliveira EM, et al. Increased clearance of reactive aldehydes and damaged proteins in hypertension-induced compensated cardiac hypertrophy: impact of exercise training. Oxid Med Cel Longevity. 2015;2015:464195.

Chan KM, Delfert D, Junger KD. A direct colorimetric assay for $\mathrm{Ca}^{2+}$-ATPase activity. Anal Biochem. 1986;157(2):375-380.

Cruz VM, Kaplan MAC. Uso medicinal de espécies das famílias Myrtaceae e Melastomataceae no Brasil. Floresta Ambiente. 2004;11(1):47-52.

Daien V, Duny Y, Ribstein J, Du Cailar G, Mimran A, Villain M, et al. Treatment of hypertension with renin-angiotensin system inhibitors and renal dysfunction: a systematic review and metaanalysis. Am J Hypertens. 2012;25(1):126-132.

Damiani CEN, Moreira CM, Zhang HT, Creazzo TL,Vassallo DV. Effects of eugenol an essential oil, on the mechanical and electrical activities of cardiac muscle. J Cardiovasc Pharmacol, 2004;44(6):688-695.

Fenech M. The in vitro micronucleus technique. Mutat Res. 2000;455(1/2):81-95.

Ferrario CM, Ahmad S, Nagata S, Simington SW, Varagic J, Kon $\mathrm{N}$, et al. An evolving story of angiotensin-II-forming pathways in rodents and humans. Clin Sci (London). 2014;126(7):461469.

Hoh JFY, Yeoh GPS, Thomas MAW, Higginbottom L. Structural differences in the heavy chains of rate ventricular myosin isoenzymes. FEBS Lett. 1979;97(2):330-334. 
Jaarin K, Foong WD, Yeoh MH, Kamarul ZY, Qodriyah HM, Azman A, et al. Mechanisms of the antihypertensive effects of Nigella sativa oil in L-NAME-induced hypertensive rats. Clinics. 2015;70(11):751-757.

Leite CM, Vassallo DV, Mill JG. Characteristics of tetanic contractions in caffeine-treated rat myocardium. Can J Physiol Pharmacol. 1995;73:638-643.

Libby P, Bonow RO, Mann D, Zipes D. Braunwald's heart disease: a textbook of cardiovascular medicine. 8.ed. Philadelphia: Saunders; 2008.

Lima GB, Silva Filho MV, Santos MG, Botas GS, Cruz RAS, Fernandes CP, et al. Chemical composition of essential oils and anticholinesterasic activity of Eugenia sulcata Spring ex Mart. Latin Am J Pharm. 2012;31(1):152-155.

Machado MM, Oliveira LFS, Zuravski L, Souza RO, Fischer P, Duarte JA, et al. Evaluation of genotoxic and cytotoxic effects of hydroalcoholic extract of Euphorbia tirucalli (Euphorbiaceae) in cell cultures of human lymphocytes. Acad Bras Cienc. 2016;88(1):17-28.

Mansour MB, Balti R, Rabaoui L, Bougatef A, Guerfel M. Chemical composition, angiotensin I-converting enzyme (ACE) inhibitory, antioxidant and antimicrobial activities of the essential oil from south Tunisian Ajuga pseudoiva Rob. Lamiaceae. Process Biochem. 2013;48(4):723-729.

Mill JG, Vassallo DV, Leite CM, Campagnaro P. Influence of the sarcoplasmic reticulum on the inotropic responses of the rat myocardium resulting from changes in rate and rhythm. Braz $\mathrm{J}$ Medic Biol Res. 1994;27:1455-1465.

Moreira CM, Oliveira EM, Bonan CD, Sarkis JJ, Vassallo DV. Effects of mercury on myosin ATPase in the ventricular myocardium of the rat. Comp Biochem Phys C Toxicol Pharmacol. 2003;135:269-275.

Negroni JA, Morotti S, Lascano EC, Gomes AV, Grandi E, Puglisi JL, et al. $\beta$-adrenergic effects on cardiac myofilaments and contraction in an integrated rabbit ventricular myocyte model. J Mol Cell Cardiol. 2015;81:162-175.

Oliveira EM, Santos RAS, Krieger JE. Standardization of a fluorometric assay for the determination of tissue angiotensinconverting enzyme activity in rats. Braz J Med Biol Res. 2000;33(7):755-764.
Piratello AC, Moraes-Silva I, Paulini J, Souza PR, Sirvente $\mathrm{R}$, Salemi V, et al. Renin angiotensin system and cardiac hypertrophy after sinoaortic denervation in rats. Clinics. 2010;65(12):1345-1350.

Santos KT, Lima BG, Tietbohl LAC, Fernandes CP, Carestiato JC, Sant'Anna LS, et al. Effects of essential oil from leaves of Eugenia sulcata Spring ex Mart. (Myrtaceae) on hemodynamic parameters of Wistar rats. Latin Am J Pharm. 2013;32(6):944947.

Santos KT, Sant'Anna LS, Bressa PAC, Tietbohl LAC, Lima BG, Fernandes CP, et al. Cardiovascular effects of the essential oil from leaves of Eugenia sulcata in spontaneously hypertensive rats. J Nat Prod. 2014;7(2014):177-183.

Santos MG, Fevereiro PCA, Reis GL, Barcelos JI. Recursos vegetais da restinga de Carapebus. Rev Biol Neotrop. 2009;6(1):35-54.

Santos-Montagner GFF, Sagrillo M, Machado MM, Almeida RC, Mostardeiro CP, Duarte MM, et al. Toxicological effects of ultraviolet radiation on lymphocyte cells with different manganese superoxide dismutase Ala16Val polymorphism genotypes. Toxicol In Vitro. 2010;24(5):1410-1416.

Schmid W. The micronucleus test. Mutat Res. 1975;31(1):9-15.

Sensch O, Vierling W, Brandt W, Reite M. Effects of inhibition of calcium and potassium currents in guinea-pig cardiac contraction: Comparison of beta caryophyllene oxide, eugenol, and nifedipine. Br J Pharmacol. 2000;131(6):1089-1096.

Sharifi N, Souri E, Ziai SA, Amin G, Amanlou M. Discovery of new angiotensin converting enzyme (ACE) inhibitors from medicinal plants to treat hypertension using an in vitro assay. DARU J Pharm Sci. 2013;21(1):74.

Simões CMO, Schenkel EP, Gosmann G, Mello JCP, Mentz LA, Petrovick PR. Farmacognosia da planta ao medicamento. $6^{\text {th }}$.ed. Porto Alegre: UFRGS; 2007.

Singh N, McCoy MT, Tice RR, Schneider EL. A simple technique for quantification of low levels of DNA damage in individuals cells. Exp Cell Res. 1995;175(1):184-191.

Sobral-Souza CE, Leite NF, Brito DI, Lavor AKLS, Alencar LBB, Albuquerque RS, et al. Avaliação da atividade citotóxica e potencial antiparasitário in vitro do $\alpha$-pineno e carvacrol. Acta Toxicol Argentina. 2014;22(2):76-80. 
Syrovy I, Delcayre C, Swynghedauw B. Comparison of ATPase activity and light subunits in myosins from left and right ventricles and atria in seven Mammalian species. J Mol Cell Cardiol. 1979;11:1129-1135.

Tamargo J, Delpón E, Valenzuela C. Treatment of left ventricular hypertrophy in hypertensive patients. Eur Heart J. 1993;14(suppl J):102-106.

Turkez H, Aydin E. In vitro assessment of cytogenetic and oxidative effects of $\alpha$-pinene. Toxicol Ind Health. 2016;32(1):168-176.
Vassallo DV, Lebarch EC, Moreira CM, Wiggers GA, Stefanon I. Lead reduces tension development and the myosin ATPase activity of the rat right ventricular myocardium. Braz J Med Biol Res. 2008;41:789-795.

Vora CK, Mansoor GA. Herbs and alternative therapies: relevance to hypertension and cardiovascular diseases. Curr Hypertens Rep. 2005;7(4):275-280.

Received for publication on $30^{\text {th }}$ November 2017 Accepted for publication on $16^{\text {th }}$ May 2018 